\title{
Expression of Fat and Cholesterol Biomarkers in Meat Goats
}

\author{
M. M. Corley ${ }^{1} \&$ J. Ward ${ }^{1}$ \\ ${ }^{1}$ Agriculture Research Station, Virginia State University, Virginia, USA \\ Correspondence: M. M. Corley, Agriculture Research Station, Virginia State University, P. O. Box 9061, \\ Petersburg, Virginia 23806, USA. Tel: 1-804-524-6802/5890. E-mail: mcorley@vsu.edu
}

Received: June 29, 2013 Accepted: August 7, 2013 Online Published: August 16, 2013

doi:10.5539/jmbr.v3n1p78 URL: http://dx.doi.org/10.5539/jmbr.v3n1p78

\begin{abstract}
Consumption of high amounts of saturated fatty acids in meat has been implicated in the onset of cardiovascular disease. Chevon (goat meat) is higher in mono-unsaturated and poly-unsaturated fatty acids than beef and lamb. Limited data is available on the expression of fat and cholesterol biomarkers in meat goats. The objective of this experiment was to determine expression of Acetyl-CoA Carboxylase (ACC1), Apoplipoproteins, A (ApoA1), and $\mathrm{B}(\mathrm{ApoB})$ in different breeds of meat goats. Protein sequence alignments were generated to determine conservation for antibody selection. The motif (SMS79 $\mathrm{pL}$ ) was conserved in the goat, human, mouse, rat and bovine $\mathrm{ACC} 1$ proteins. The ApoA1 and ApoB protein alignments (human, bovine and rabbit) revealed high protein sequence homology. The Enzyme-Linked Immunosorbent Assay (ELISA) was used to determine serum ACC1, ApoA1 and ApoB in Spanish and Myotonic goats. Spanish goats had higher $(\mathrm{P}<0.05)$ ACC1 than Myotonic goats. There was a gender effect $(\mathrm{P}<0.05)$ where females expressed more ACC1 than males. Breed and gender differences were detected in Spanish and Myotonic goats, with Spanish goats showing $37 \%$ more $(\mathrm{P}<0.05)$ ApoA1 expression in the blood than Myotonic goats and female goats with $47 \%$ higher expression of ApoA1 than males. Inversely, Myotonic goats expressed 35\% higher $(\mathrm{P}<0.05)$ levels of ApoB than Spanish goats and males had $46 \%$ higher $(\mathrm{P}<0.05)$ ApoBexpression than females. These data demonstrate that inherent differences exist in lipid metabolism of meat goats and can lead to lipid biomarker assisted breeding programs to produce a heart, healthy red meat for human consumption.
\end{abstract}

Keywords: Acetyl Co-A carboxylase, apolipoproteins, ApoA1, ApoB, meat goat

\section{Introduction}

\subsection{Significance of the Problem}

A molecular genetics approach to enhance global meat goat production is very much in the infancy stage. Goat production continues to gain attention because of the potentially beneficial impact of chevon (goat meat) consumption on human health (Bourre, 2005). Chevon is a source of high quality animal protein with relatively less fat and marginal cholesterol when compared to similarly prepared beef or lamb. Goats deposit fat primarily internally as opposed to intramuscularly which is why chevon is a lean red meat compared to traditional beef, lamb or pork (Banskalieva, Sahlu, \& Goetsch, 2000; Liméa, Alexandre, \& Berthelot, 2012). The saturated fat content in cooked goat meat has been reported to be up to $40 \%$ lower than that of skinless chicken and 50-65\% lower than similarly prepared beef (James \& Berry, 1997). Goat meat also contains a relatively high amount of polyunsaturated fatty acids (PUFA) consisting mostly of linoleic, linolenic, and arachidonic acids (Banskalieva et al., 2000). According to the National Health and Nutrition Examination Survey (NHANES) statistics published by NIH, 12.5 million children and adolescents aged 2-19 years are obese. Consumption of high amounts of saturated fatty acids can affect the serum lipid profile (Mateo-Gallego et al., 2011) and the tissue lipid profile primarily in the total and low-density lipoprotein (LDL) cholesterol fractions (Glew et al., 2010). These factors are associated with an increased risk for developing obesity and subsequently cardiovascular disease (CVD) (Cascio, Schiera \& Di Liegro, 2012). Genes that control the fatty acid profile in humans have been extensively studied in both humans and animals (Zulet \& Martinez, 1995; Chilliard et al., 2001; Vincent et al., 2002; Viturro et al., 2009), but not much in meat goats. Much attention has been focused on Acetyl-CoA carobxylase (ACC1), which is the rate-limiting enzyme that catalyzes the carboxylation of acetyl-CoA to form malonyl-CoA, the first step in the synthesis of long chain fatty acids (LCFA) de novo. After malonyl-CoA formation another complex of enzymes, the fatty acid synthetase system (FAS), takes over catalyzing the rest of the synthesis. The end product of long chained fatty acid (LCFA) biosynthesis catalyzed by ACC1 and FAS in 
humans and animals, (Cánovas, Estany, Tor, Pena, \& Doran, 2009; Zhang et al., 2010) is palmitic acid, one of the saturated fatty acids (SFA) implicated in coronary heart disease (Mensink, Temme, \& Hornstra, 1994; Mensink, 1993). The apolipoprotein B (ApoB) gene controls the low density lipoprotein (LDL) levels in the body. The LDL cholesterol has been identified as the primary target for therapy in terms of reducing the risk for coronary heart disease (CHD) (Couvert et al., 2008). This LDL cholesterol can build up on the walls of arteries and increase the chances of getting heart disease. Consequently LDL cholesterol is referred to as "bad" cholesterol. The apolipoprotein A1 (ApoA1) gene regulates the level of high density lipoprotein (HDL) ("good" cholesterol) in the body. Research efforts are ongoing to find mechanisms to increase HDL cholesterol and the ratio of HDL: LDL (Gilmore et al., 2011; Gonzalez-Requejo et al., 1995; Harris et al., 2004; Sanchez-Muniz, Bastida, Viejo, \& Terpstra, 1999). The HDL cholesterol protects against heart disease by taking the LDL cholesterol out of the blood and preventing it from building up in the arteries. The higher the HDL number, the lower the risk for CVD. High-density lipoprotein cholesterol accounts for about one-fourth to one-third of the total blood cholesterol. The HDL carries cholesterol and cholesterol esters away from the peripheral arteries and back to the liver, where it is passed from the body through reverse cholesterol transport (Daniels et al., 2010) Goats do not deposit fat intramuscularly, and therefore the unsaturated fat content is lower in chevon (Dhanda, Taylor, Murray, \& McCosker, 1999).

\subsection{Justification}

It is known that diet can influence intramuscular fat in goats. Studies have shown that Boer x Spanish goats grazed on pasture without any grain supplementation is more saturated than intramuscular fat from goats fed a grain diet (Banskalieva et al., 2000; Ding, Kou, Cao, \& Wei, 2010; Rhee, Waldron, Ziprin, \& Rhee, 2000; Tan et al., 2011). In addition to diet, genotype can influence the lipid profile of both humans (Guzmán, Hirata, Quintão, \& Hirata, 2000; Minihane et al., 2000; Salazar, Hirata, Quintão, \& Hirata, 2000) and animals (Dhanda, Taylor, McCosker, \& Murray, 1999; Hoashi et al., 2008; Maharani et al., 2012). Very limited molecular work has been done on the genes that control the lipid profile in meat goats. This study evaluated serum protein expression of genes that control the lipid profile in different breeds of meat goats.

\section{Method}

\subsection{Animals and Experimental Design}

Animals used for the study were housed at Virginia State University Randolph farm in accordance with animal care and use guidelines. A total of 20 Spanish and Myotonic goats (5 males, 5 non-pregnant females of each breed), grazing pasture and supplemented with hay, cracked corn and ground soybean meal were selected from a screened pool of over 100 goats (Corley \& Jarmon, 2012). A total of three trials were conducted.

\subsection{Blood Collection and Serum Preparation}

Goats were adequately restrained and blood collected via jugular venipuncture. In brief, the vein was identified by palpation and visual inspection. The area was clipped and swabbed with $70 \%$ alcohol. Gentle pressure was applied at the thoracic inlet to produce distension of the vein. Blood samples $(3 \mathrm{ml})$ were collected in vials without anti-coagulant using $16-20 \mathrm{G}$ needles. Blood samples were placed in a swinging bucket centrifuge and spun at 10, $000 \mathrm{rpm}$. Serum was removed and subsequently stored at $-80{ }^{\circ} \mathrm{C}$ for later protein analysis.

\subsection{Screening and Selection of Antibodies for ACC1, ApoA1 and ApoB Protein Analysis}

Before antibody selection, a comprehensive screening of the GenBank protein databases was performed. The $\mathrm{ACC} 1, \mathrm{ApoB}$ and ApoA1 protein target information was obtained from the product information published by the antibody manufacturing company (Abcam, Cambridge, MA). For the ACC1 antibody, specific target information (serine $\mathrm{p}^{79}$ phosphorylated residue) was available. For the ApoA1 and ApoB antibodies only GenBank Accession numbers were available. Using this information as a guide, protein sequences (goat, sheep, bovine, human, rabbit) were retrieved from the GenBank and sequence alignments generated (Figure 1, 2, 3) using CLC Main Workbench Bioinformatics software (clcbio.com). Observation of conserved sequence homology enabled a more specific selection of the antibodies for this study. 


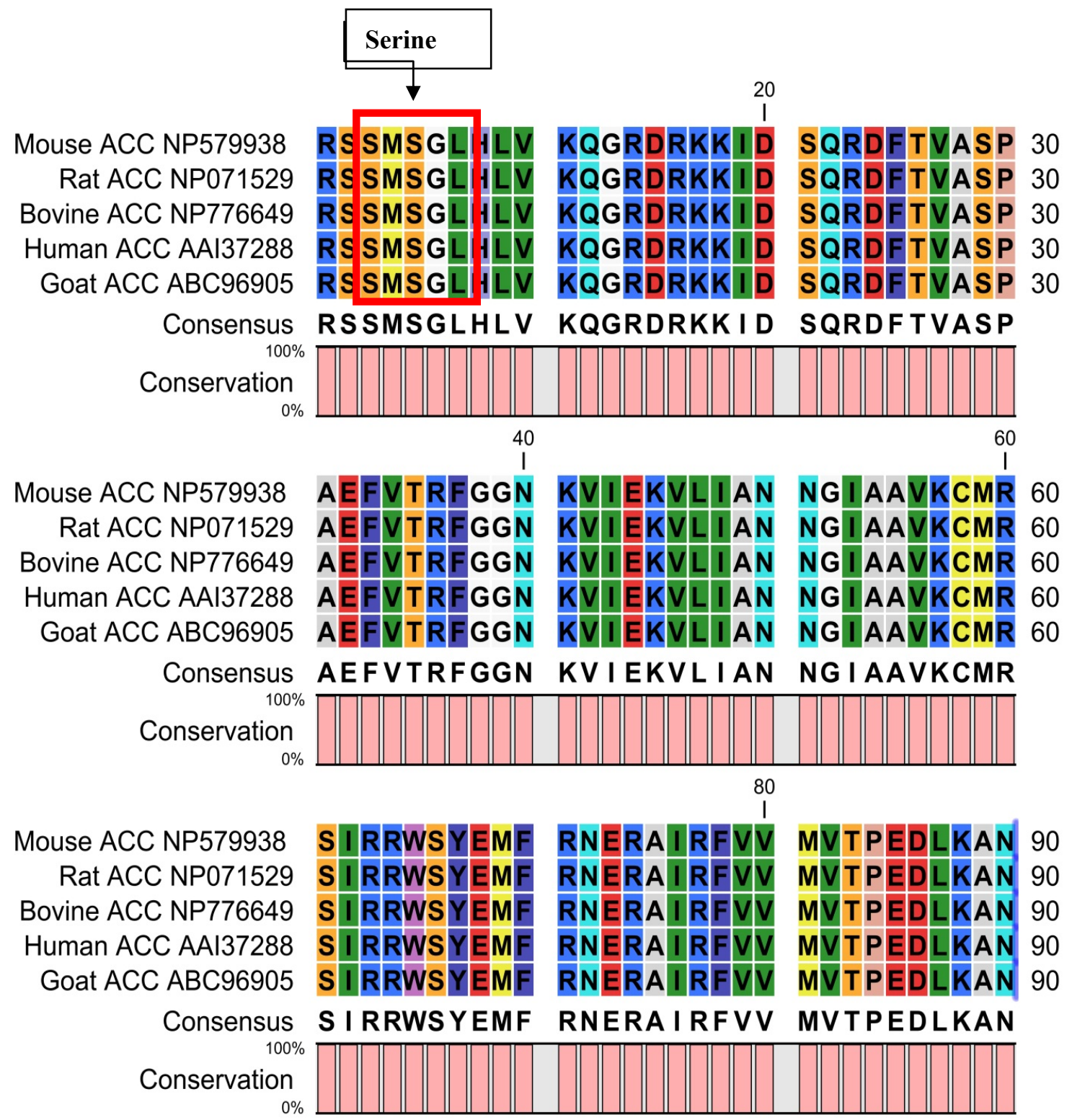

Protein sequence alignment of the Acetyl CoA Carboxylase1 gene, including the goat: The serine $79^{\mathrm{p}}$ region of the protein from which the antibody was designed is conserved among all species and is shown in the outlined box. An alignment was done before antibody selection to determine sequence conservation among the ACC1 proteins and the possibility of the human $\mathrm{ACC} 1$ antibody's use to detect the $\mathrm{ACC} 1$ protein in goat serum.

Figure 1. Protein sequence alignment of Acetyl-CoA Carboxylase (ACC1) genes showing conserved ACC1 antibody target region 


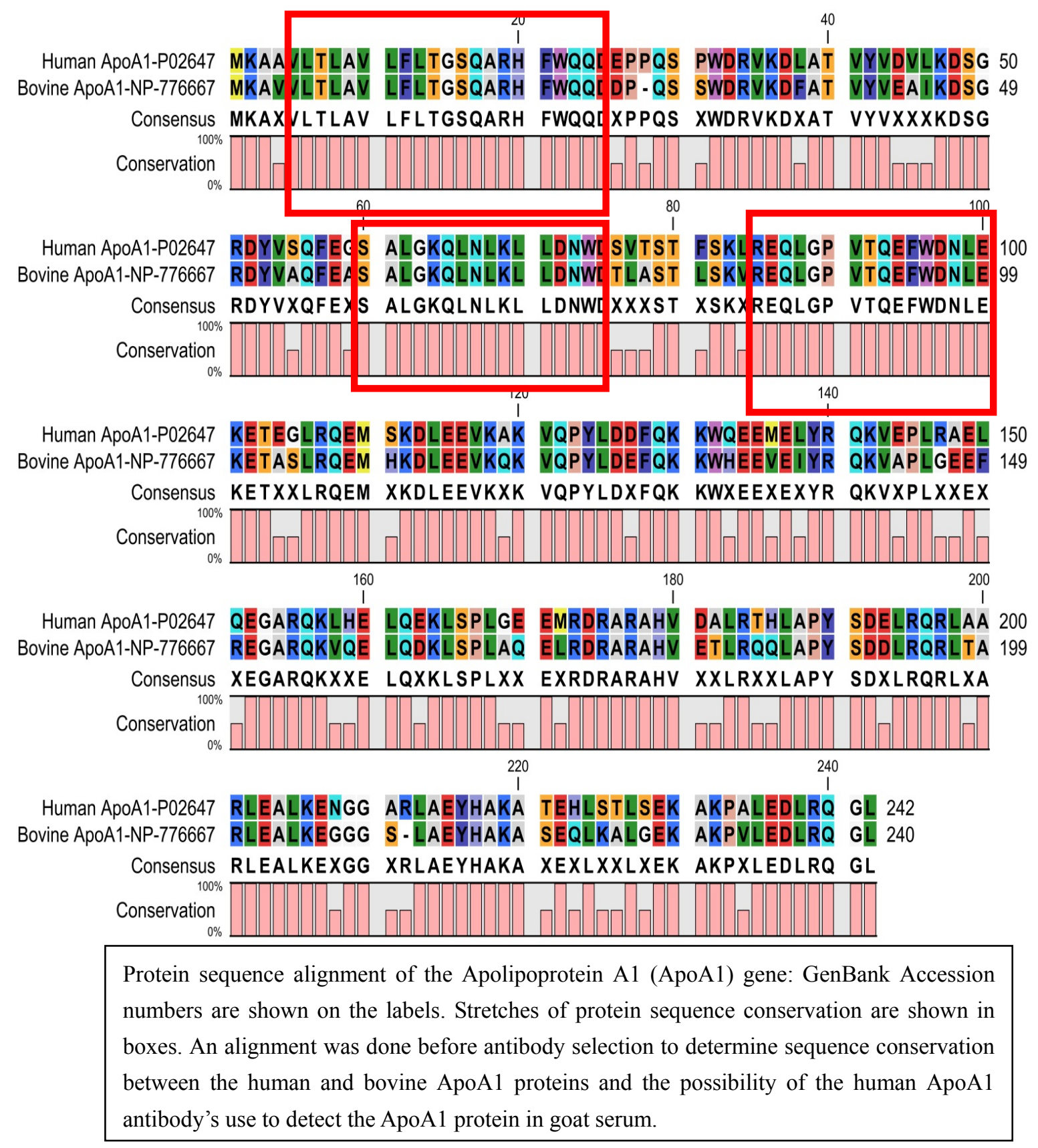

Figure 2. Protein sequence alignment of Apolipoprotein A1 (ApoA1) genes showing conserved ApoA1 potential antibody target regions 


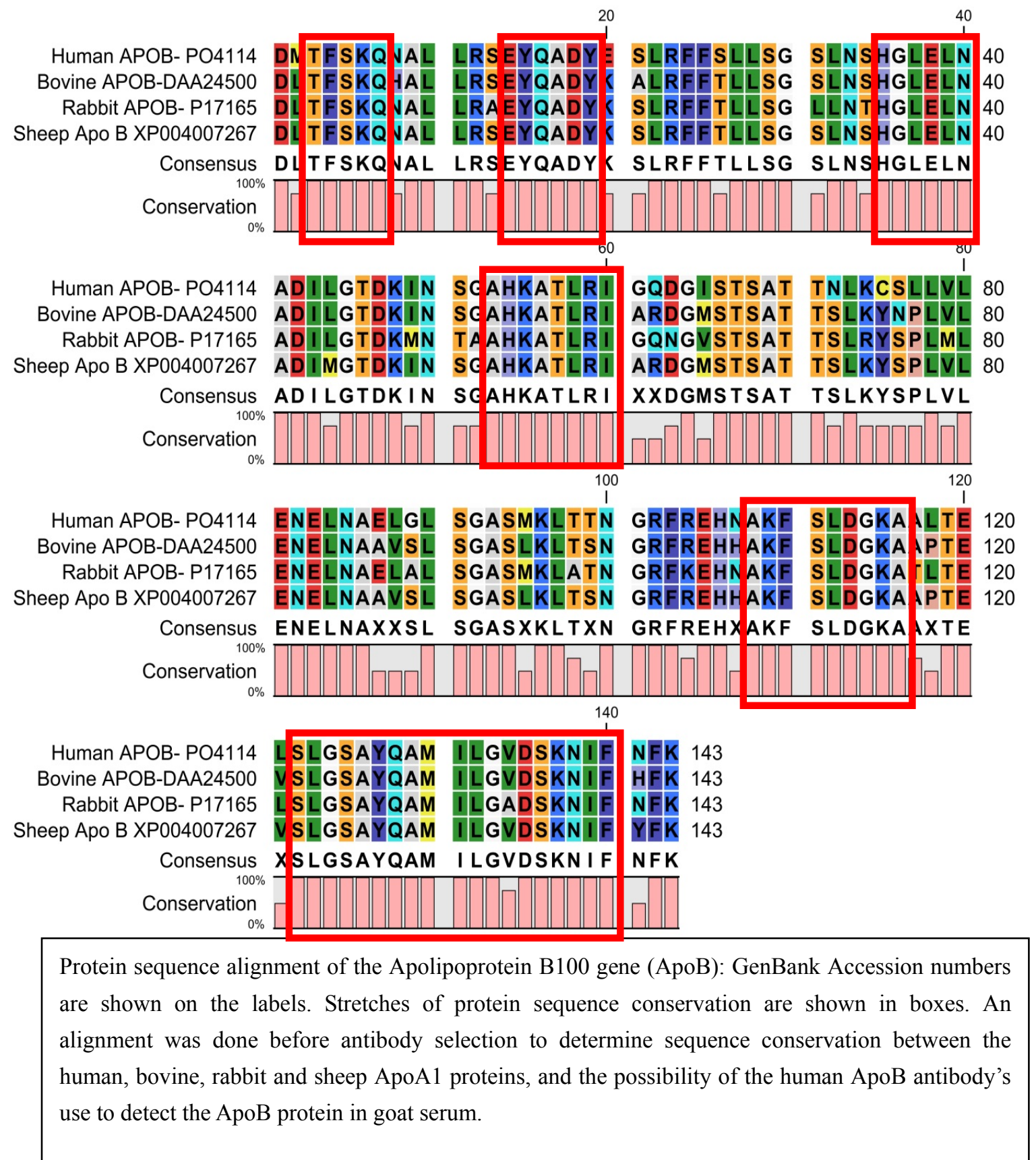

Figure 3. Protein sequence alignment of Apolipoprotein B (ApoB) genes showing conserved ApoB potential antibody target regions 


\subsection{Analysis of Acetyl-CoA Carboxylase (ACC1), ApoA1 and ApoB}

To determine ACC1, APOA1 and APOB serum concentrations, an indirect ELISA was performed using Anti-Acetyl Coenzyme A Carboxylase, Rabbit polyclonal to Acetyl Coenzyme A Carboxylase, Goat polyclonal to Apolipoprotein A I and Goat polyclonal to Apolipoprotein B antibodies respectively (AbCam, Cambridge, MA). To the top wells of a PCV microtiter 96 well plate, $50 \mu 1$ antigen standards $(20 \mathrm{~g} / \mathrm{ml})$ and serum samples dissolved in coating buffer (100mM: $3.03 \mathrm{~g} \mathrm{Na}_{2} \mathrm{CO}_{3}, 6.0 \mathrm{~g} \mathrm{NaHCO}$ ) was added and serially diluted 10 fold. The plate was then covered with adhesive tape and incubated for two hours at room temperature. The coating solution was discarded in a decontamination pan. The plate was then washed a total of two times by filling all wells with $300 \mu \mathrm{l}$ of wash solution PBS (pH 7.4) with $0.05 \%(\mathrm{v} / \mathrm{v})$ Tween20, waiting 1 minute, and then discarding the liquid into a decontamination pan. The remaining drops were then removed by gently tapping the plate on a thick piece of paper towel. The remaining protein binding sites in the coated wells were blocked by adding $200 \mu \mathrm{l}$ of blocking buffer (1\% BSA). The plate was then covered with adhesive plastic and incubated at 4 ${ }^{\circ} \mathrm{C}$ for $1 \mathrm{hr}$. The plate was then washed twice as previously described. After tap drying, $100 \mu \mathrm{l}$ of the primary antibody was added to the plate. The plate was covered with adhesive plastic and incubated for 1 hour at room temperature and washed three times as previously described. To each well $100 \mu \mathrm{l}$ of the secondary antibody (HRP-anti-goatIgG) was added. Adhesive tape was placed over the plate and incubated at room temperature for thirty minutes. The plate was then washed three times after which $100 \mu \mathrm{l}$ of TMB substrate (Bethyl Labs Inc.) solution was added to each well and incubated for 15 minutes in the dark. The chromogenic reaction was stopped by addition of $100 \mu \mathrm{l}$ of stop solution to each well. Samples (triplicate) were read in an iMarkmicroplate reader (BioRad) at $450 \mathrm{~nm}$. Standard curves were generated using the microplate manager 6 software and concentrations of ACC1, ApoA1 and ApoB proteins determined. Data were exported for statistical analysis.

\subsection{Statistical Analysis}

All data were analyzed using the General Linear Model procedure of SAS. To account for trial $(n=3)$ differences, the data were analyzed in a Randomized Complete Block Design. Means were considered significant at the 5\% level of probability.

\section{Results and Discussion}

Biomarkers of fat and cholesterol are of interest because chevon (goat meat) is naturally lower in fat and cholesterol than beef and lamb (Banskalieva et al., 2000; Rhee, Cho, \& Pradahn, 1999), and can be the alternative heart healthy red meat in the hopes of controlling obesity and CVD. Goat producers would have the opportunity to engage in fat and cholesterol biomarker assisted breeding programs, and can therefore maximize production of a red meat that is low in fat and cholesterol. This study was conducted to test the hypothesis that different breeds of meat goats on the same diet would have different fatty acid and cholesterol profiles. Because the goat anti-ACC1, anti-ApoA1 and anti-ApoB were not readily available, a screening of the protein sequence databases (ncbi.nih.nlm.gov) of each biomarker was performed. Cross species protein sequence alignments of ACC1, ApoA1 and ApoB aided in antibody selection for the ELISA. As a result it was possible to quantify protein expression levels of ACC1, ApoA1 and ApoB in the serum of Spanish and Myotonic goats.

\subsection{ACC1 Expression}

The ACC1 antibody binds to mouse rat and human ACC1 and was derived from the human Acetyl CoA Carboxylase around the phosphorylation site of serine 79. In this study, the ACC1 antibody was successful in detecting ACC1 in goat serum. For selection of the anti-ACC1, assurance that the human anti-ACC1 could bind the goat $\mathrm{ACC} 1$ was evident in the presence of the SMS79 $\mathrm{GL}$ moiety in the goat, bovine, human, mouse, and rat protein sequence alignments (Figure 1). This same moiety was present in the ACC1 antibody from the manufacturer. Spanish goats had higher $(\mathrm{P}<0.05)$ ACC1 than Myotonic goats. More specifically, in Spanish goats, expression of ACC1 was $49 \%$ higher than in Myotonic goats (Figure 4). 


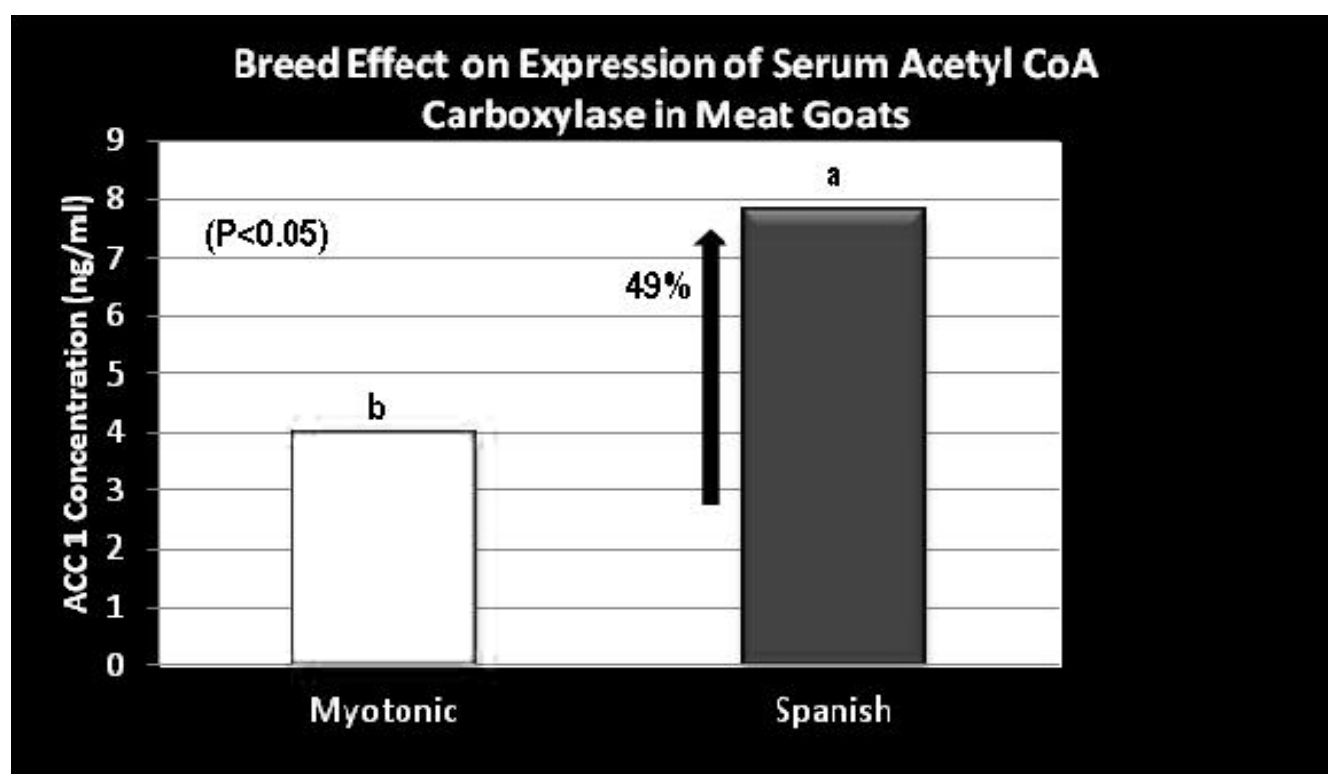

Figure 4. Breed effect on expression of Acetyl-CoA Carboxylase in meat goats

Breed Effect on Expression of AcetylCoA Carboxylase in Meat Goats as measured by ELISA: ab, Means with different letters differ $(\mathrm{P}<0.05)$. Arrows indicate the margin of increase in $\mathrm{ACC} 1$ expression. This increase was calculated as a percentage difference between mean serum ACC1 concentrations.

Results of the ELISA in this study showed that Spanish goats expressed higher ACC1 than Myotonic goats, indicating that different breeds of meat goats could inherently have different fatty acid metabolism. Studies have shown that genotype has an effect on the fatty acid profile and cholesterol levels of meat (Hoashi et al., 2008) (Daniels et al., 2010; Peña et al., 2009). In the case of gender, female goats expressed $45 \%$ more $(\mathrm{P}<0.05)$ ACC1 than males (Figure 5).

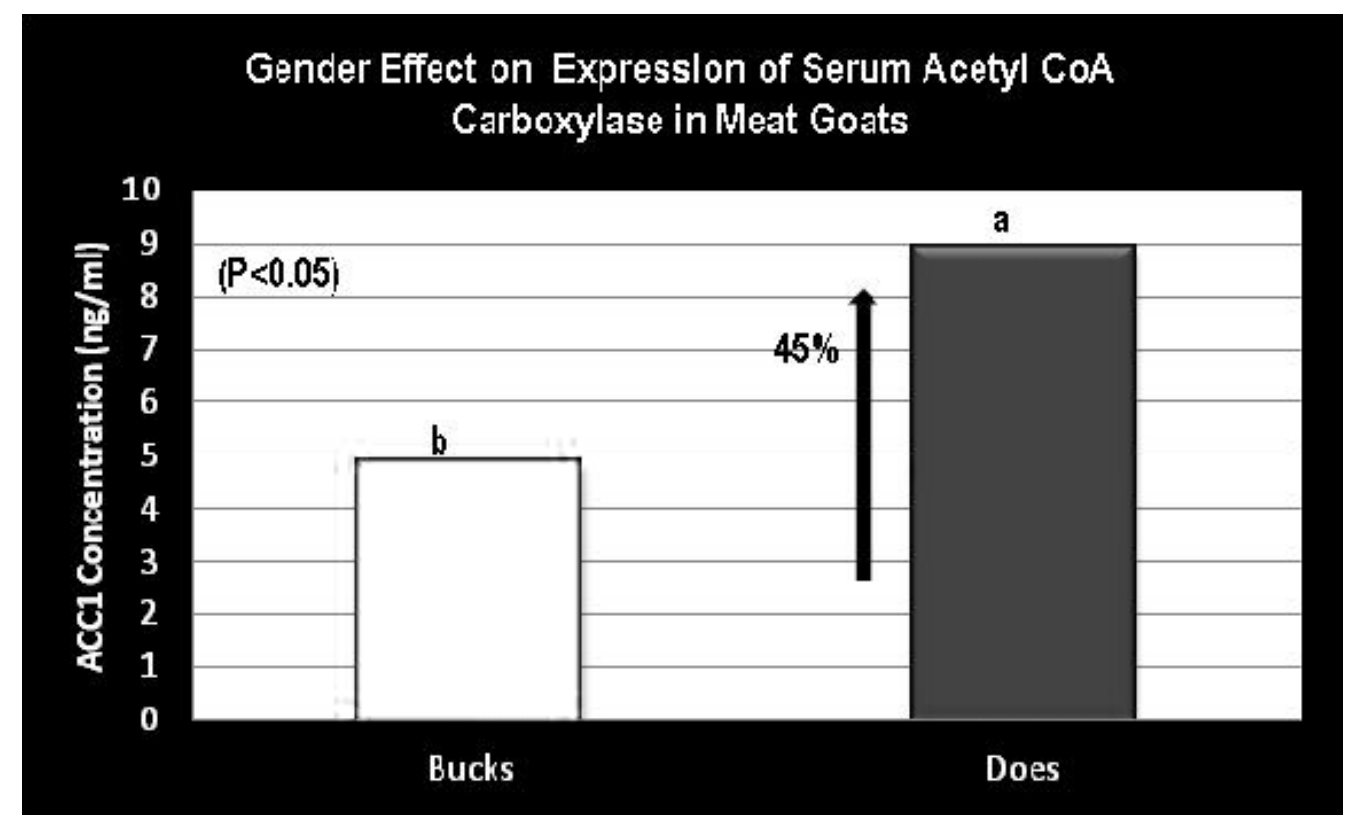

Figure 5. Gender effect on expression of Acetyl-CoA Carboxylase in meat goats

Expression of Acetyl CoA Carboxylase in male and female goats as measured by ELISA: ab, Means with different letters differ $(\mathrm{P}<0.05)$. Arrows indicate the margin of increase in ACC1 expression. This increase was calculated as a percentage difference between mean serum $\mathrm{ACC} 1$ concentrations. 
It has been shown that gender can affect long chain fatty acid synthesis in humans. Significantly lower values of fatty acids were observed in men than in women (Knopp et al., 2005; Lohner, Fekete, Marosvölgyi, \& Decsi, 2013). This is supporting evidence that gender needs to be taken into consideration when evaluating the lipid profile. To put this in the context of meat goats, if fat biomarker assisted breeding selection is used in production of chevon gender would have to be considered. Very few studies have addressed the expression of ACC1 in meat goats. Thus far expression of ACC1 has been conducted in other breeds of meat goats and only on the genomic level (Solaiman, Min, Gurung, Behrends, \& McElhenney, 2012). Our study evaluated protein expression of $\mathrm{ACC} 1$ in Spanish and Myotonic goats focusing more on the translational level of ACC1 expression. These data demonstrate the first step in answering the question whether different breeds of meat goats on the same diet, have different fatty acid metabolism, therefore a different fatty acid profile.

\subsection{Apo Al and ApoB Expression}

The selected anti-ApoA1 and anti-ApoB proteins successfully bound to the goat ApoA1 and ApoB as evidenced by the ELISA. In the case of ApoA1 and ApoB, the antibodies were designed from the whole native proteins and no specific target region information was available. However, the manufacturer did provide the UNIPROT database Accession numbers from which the antibodies were designed, as was observed from the protein sequence alignments (Figure 2 and 3). The ApoA1 antibody was the full length native ApoA1 and reacts with human ApoA1. Breed and gender differences were detected in Spanish and Myotonic goats, with Spanish goats showing 37\% more $(\mathrm{P}<0.05)$ ApoA1 expression in the blood than Myotonic goats (Figure 6) and female goats with $47 \%$ higher expression of ApoA1 than males (Figure 7). In the case of HDL, Spanish goats expressed more of the HDL ("good cholesterol") biomarker (ApoA1) than Myotonic goats. This implies that genotype can play a role in expression of cholesterol biomarkers in the blood. Other studies have shown that breed does influence the level of cholesterol in the body (Anil, 2007; Ding et al., 2010; Wheeler, Davis, Stoecker, \& Harmon, 1987).

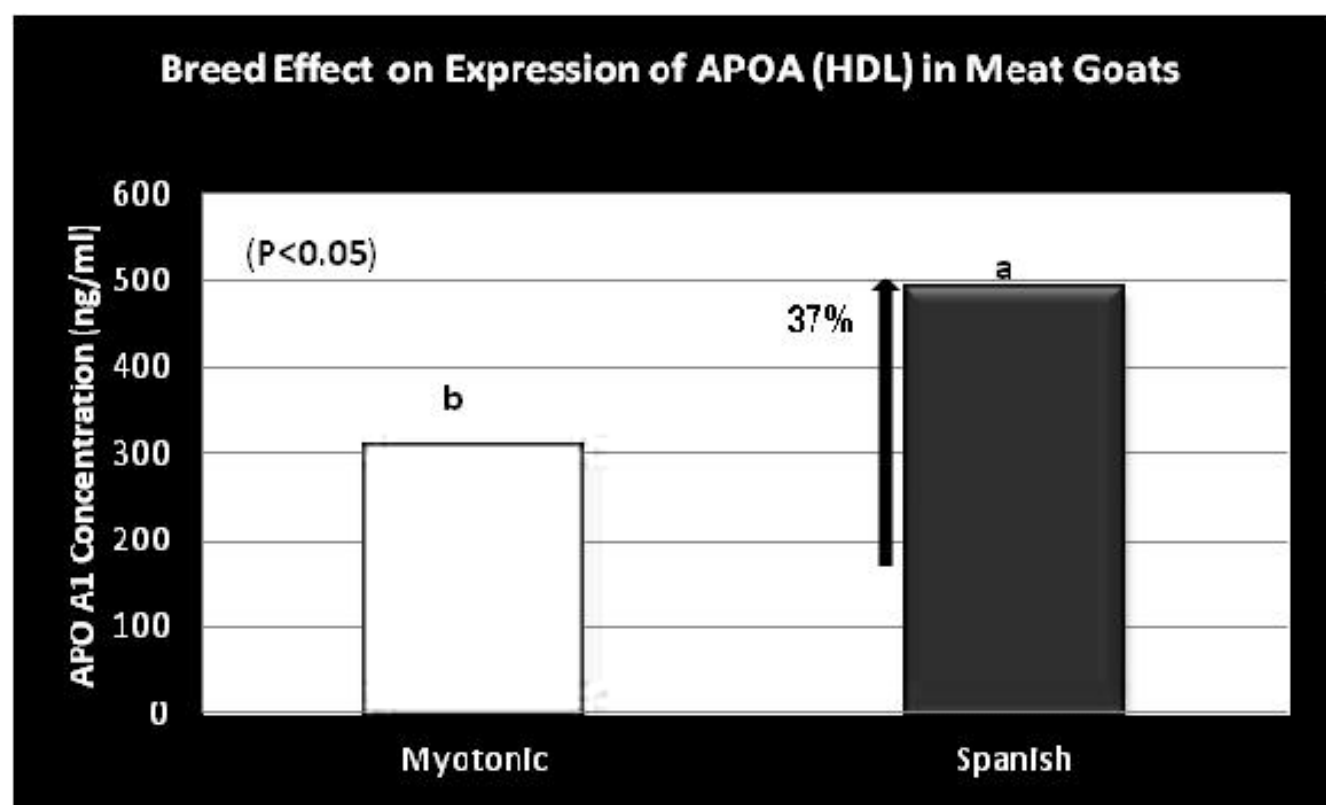

Figure 6. Breed effect on expression of apolipoprotein A1 (ApoA1) in meat goats

Expression of Apolipoprotein A 1 in Spanish and Myotonic goats as measured by ELISA: ab, Means with different letters differ $(\mathrm{P}<0.05)$. Arrows indicate the margin of increase in APOA1 expression. This increase was calculated as a percentage difference between mean serum APO A1 concentrations. 


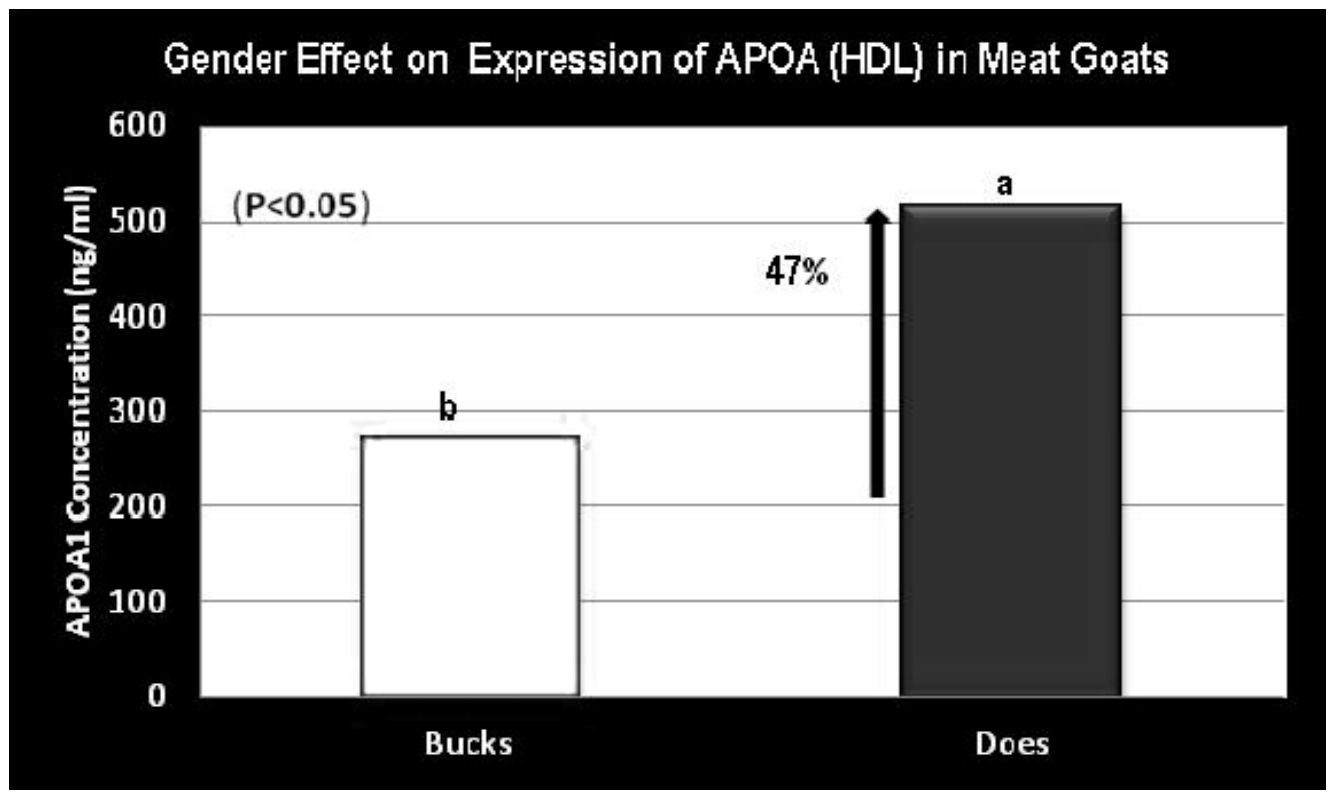

Figure 7. Gender effect on expression of apolipoprotein A1 (ApoA1) in meat goats

Expression of Apolipoprotein A1 in male and female goats as measured by ELISA: ab, Means with different letters differ $(\mathrm{P}<0.05)$. Arrows indicate the margin of increase in APOA1 expression. This increase was calculated as a percentage difference between mean serum APO A1 concentrations.

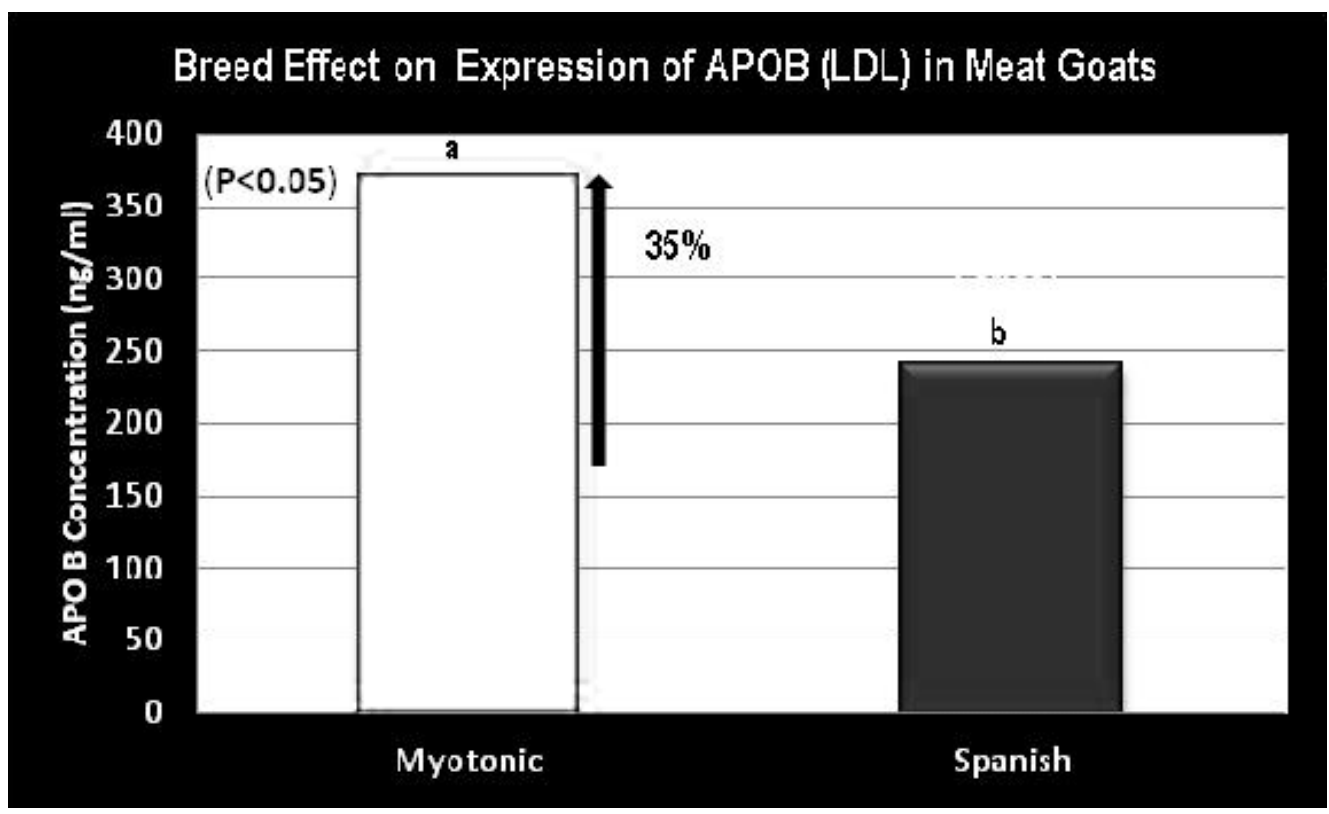

Figure 8. Breed effect on expression of apolipoprotein B (ApoB) in meat goats

Expression of Apolipoprotein B in Spanish and Myotonic goats as measured by ELISA: ab, Means with different letters differ $(\mathrm{P}<0.05)$. Arrows indicate the margin of increase in APOB expression. This increase was calculated as a percentage difference between mean serum APO B concentrations. 


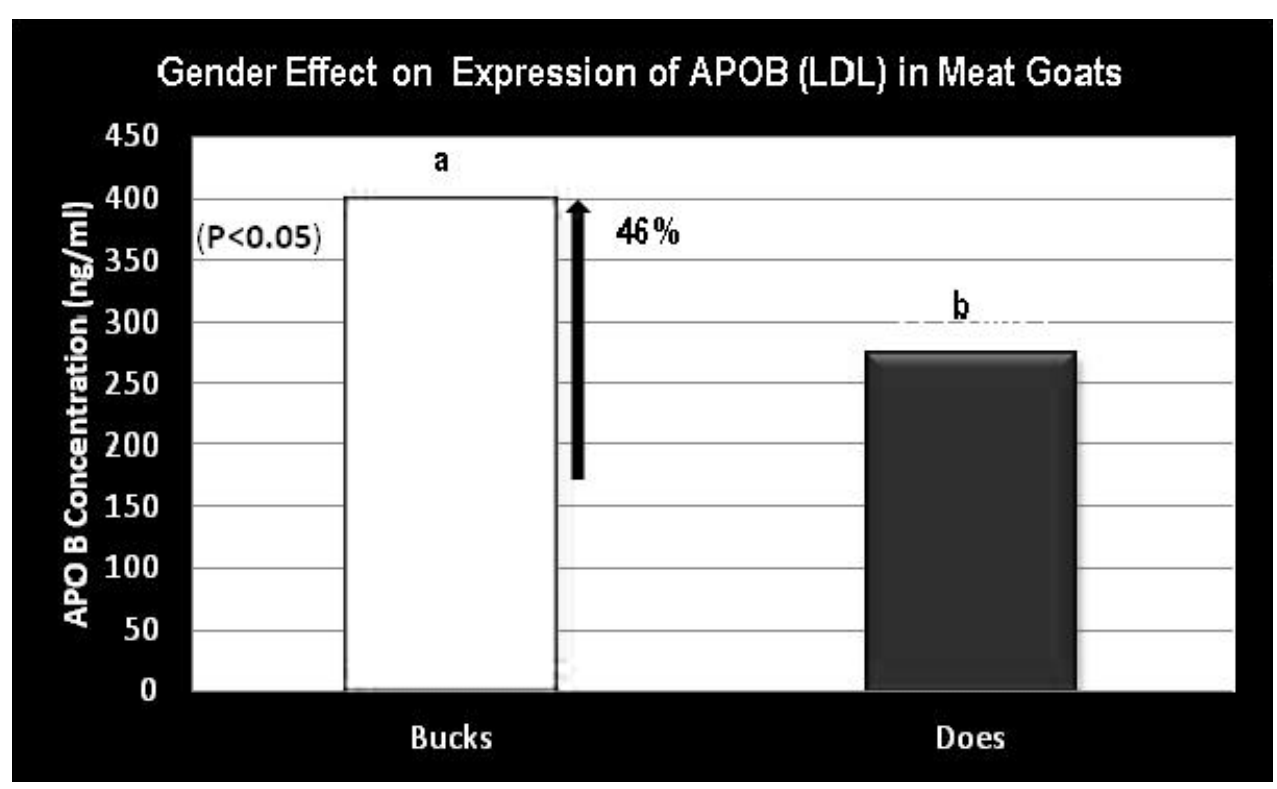

Figure 9. Gender Effect on Expression of Apolipoprotein B (ApoB) in Meat Goats

Expression of Apolipoprotein B in male and female goats as measured by ELISA: ab, Means with different letters differ $(\mathrm{P}<0.05)$. Arrows indicate the margin of increase in APOB expression. This increase was calculated as a percentage difference between mean serum $\mathrm{APOB}$ concentrations.

The ApoB (full length) antibody has binding affinity to both rabbit and human. Myotonic goats expressed 35\% higher $(\mathrm{P}<0.05)$ levels of ApoB than Spanish goats (Figure 8) and males had $46 \%$ higher $(\mathrm{P}<0.05)$ ApoB expression than females (Figure 9). Myotonic goats expressed more of the LDL ("bad cholesterol") biomarker (ApoB) than Spanish goats. It has been demonstrated that defective apoB 100 gene results in increased plasma levels of total cholesterol and LDL cholesterol (Al-Khateeb, Al-Talib, Mohamed, Yusof, \& Zilfalil, 2013) again demonstrating that genotype plays a role in cholesterol metabolism (Couvert et al., 2008; Daniels et al., 2010). Females had higher expression of the HDL biomarker than males. This finding supports that of other studies in which gender effect is linked more to protein expression of ApoA1. It was shown that in castrated mice testosterone and estrogen altered the protein synthesis of ApoA-I in castrated inbred strains of mice, but apoA-I mRNA levels remained unaltered, indicating post-transcriptional regulation of the ApoA-I production in liver. As with ApoA1 expression, gender was a contributing factor as males had higher ApoB expression than females. It is already established that gender can play a role in the development of hypercholesterolemia (Beauchesne-Rondeau, Gascon, Bergeron, \& Jacques, 2003; Hoogerbrugge et al., 2001). Therefore it is evident from the baseline data given in this study that inherent differences can play an integral role in the outcome of the lipid profile in meat goats.

\section{Conclusion}

These data demonstrate that cross species binding affinity of antibodies can be useful in determining the level of protein expression of ACC1, ApoA1, and ApoB in meat goats. Therefore protein expression can be influenced by breed and gender, in meat goats and can therefore allow assessment of their lipid profile. Knowledge of the expression of biomarkers of fat and cholesterol in meat goats is essential to understanding the baseline from which an enhanced goat meat product can be produced. This would lead chevon producers to consider breed and gender selection in the production of an alternative healthy red meat for human consumption. Further studies are underway to test the effect of diets high in omega 3 and 6 fatty acids in the hopes of development of a heart healthy enhanced red meat (omega-chevon ( )).

\section{Acknowledgements}

The authors would like to thank the Virginia State University animal care and laboratory staff. This research was funded by USDA-EVANS ALLEN grant at the Virginia State University Agricultural Research Station, Petersburg, Virginia. Journal Article Series No.: 307. 


\section{References}

Al-Khateeb, A., Al-Talib, H., Mohamed, M. S., Yusof, Z., \& Zilfalil, B. A. (2013). Phenotype-genotype analyses of clinically diagnosed Malaysian familial hypercholestrolemic patients. Adv Clin Exp Med, 22(1), 57-67.

Anil, E. (2007). The impact of EPA and DHA on blood lipids and lipoprotein metabolism: influence of apoE genotype. Proc Nutr Soc, 66(1), 60-68. http://dx.doi.org/10.1017/S0029665107005307

Banskalieva, V., Sahlu, T., \& Goetsch, A. L. (2000). Fatty acid composition of goat muscles and fat depots: a review. Small Rumin Res, 37(3), 255-268. http://dx.doi.org/10.1016/S0921-4488(00)00128-0

Beauchesne-Rondeau, E., Gascon, A., Bergeron, J., \& Jacques, H. (2003). Plasma lipids and lipoproteins in hypercholesterolemic men fed a lipid-lowering diet containing lean beef, lean fish, or poultry. Am J Clin Nutr, 77(3), 587-593.

Bourre, J. M. (2005). Effect of increasing the omega-3 fatty acid in the diets of animals on the animal products consumed by humans. Med Sci (Paris), 21(8-9), 773-779. http://dx.doi.org/10.1051/medsci/2005218-9773

Cánovas, A., Estany, J., Tor, M., Pena, R. N., \& Doran, O. (2009). Acetyl-CoA carboxylase and stearoyl-CoA desaturase protein expression in subcutaneous adipose tissue is reduced in pigs selected for decreased backfat thickness at constant intramuscular fat content. $J$ Anim Sci, 87(12), 3905-3914. http://dx.doi.org/10.2527/jas.2009-2091

Chilliard, Y., Bonnet, M., Delavaud, C., Faulconnier, Y., Leroux, C., Djiane, J., ... Bocquier, F. (2001). Leptin in ruminants. Gene expression in adipose tissue and mammary gland, and regulation of plasma concentration. Domest Anim Endocrinol, 21(4), 271-295. http://dx.doi.org/10.1016/S0739-7240(01)00124-2

Corley, M. M., \& Jarmon, A. A. (2012). Interleukin 13 as a Biomarker for Parasite Resistance in Goats Naturally Exposed to Haemonchus contortus. Journal of Agricultural Science, 4(7), 31-40. http://dx.doi.org/10.5539/jas.v4n7p31

Couvert, P., Giral, P., Dejager, S., Gu, J., Huby, T., Chapman, M. J., \& Carrié, A. (2008). Association between a frequent allele of the gene encoding OATP1B1 and enhanced LDL-lowering response to fluvastatin therapy. Pharmacogenomics, 9(9), 1217-1227. http://dx.doi.org/10.2217/14622416.9.9.1217

Daniels, T. F., Wu, X. L., Pan, Z., Michal, J. J., Wright, R. W., Killinger, K. M., ... Jiang, Z. (2010). The reverse cholesterol transport pathway improves understanding of genetic networks for fat deposition and muscle growth in beef cattle. PLoS One, 5(12), e15203. http://dx.doi.org/10.1371/journal.pone.0015203

Dhanda, J. S., Taylor, D. G., McCosker, J. E., \& Murray, P. J. (1999). The influence of goat genotype on the production of Capretto and Chevon carcasses. 1. Growth and carcass characteristics. Meat Sci, 52(4), 355-361. http://dx.doi.org/10.1016/S0309-1740(99)00016-9

Dhanda, J. S., Taylor, D. G., Murray, P. J., \& McCosker, J. E. (1999). The influence of goat genotype on the production of Capretto and Chevon carcasses. 4. Chemical composition of muscle and fatty acid profiles of adipose tissue. Meat Sci, 52(4), 375-379. http://dx.doi.org/10.1016/S0309-1740(99)00014-5

Ding, W., Kou, L., Cao, B., \& Wei, Y. (2010). Meat quality parameters of descendants by grading hybridization of Boer goat and Guanzhong Dairy goat. Meat Sci, 84(3), 323-328. http://dx.doi.org/10.1016/j.meatsci.2009.04.015

Gilmore, L. A., Walzem, R. L., Crouse, S. F., Smith, D. R., Adams, T. H., Vaidyanathan, V., ... Smith, S. B. (2011). Consumption of high-oleic acid ground beef increases HDL-cholesterol concentration but both high- and low-oleic acid ground beef decrease HDL particle diameter in normocholesterolemic men. J Nutr, 141(6), 1188-1194. http://dx.doi.org/10.3945/jn.110.136085

Glew, R. H., Chuang, L. T., Berry, T., Okolie, H., Crossey, M. J., \& VanderJagt, D. J. (2010). Lipid profiles and trans fatty acids in serum phospholipids of semi-nomadic Fulani in northern Nigeria. J Health Popul Nutr, 28(2), 159-166.

Gonzalez-Requejo, A., Sanchez-Bayle, M., Baeza, J., Arnaiz, P., Vila, S., Asensio, J., \& Ruiz-Jarabo, C. (1995). Relations between nutrient intake and serum lipid and apolipoprotein levels. J Pediatr, 127(1), 53-57. http://dx.doi.org/10.1016/S0022-3476(95)70256-3.

Guzmán, E. C., Hirata, M. H., Quintão, E. C., \& Hirata, R. D. (2000). Association of the apolipoprotein B gene polymorphisms with cholesterol levels and response to fluvastatin in Brazilian individuals with high risk for coronary heart disease. Clin Chem Lab Med, 38(8), 731-736. http://dx.doi.org/10.1515/CCLM.2000.103 
Harris, K. B., Pond, W. G., Mersmann, H. J., Smith, E. O., Cross, H. R., \& Savell, J. W. (2004). Evaluation of fat sources on cholesterol and lipoproteins using pigs selected for high or low serum cholesterol. Meat Sci, 66(1), 55-61. http://dx.doi.org/10.1016/S0309-1740(03)00012-3

Hoashi, S., Hinenoya, T., Tanaka, A., Ohsaki, H., Sasazaki, S., Taniguchi, M., ... Mannen, H. (2008). Association between fatty acid compositions and genotypes of FABP4 and LXR-alpha in Japanese black cattle. BMC Genet, 9, 84. http://dx.doi.org/10.1186/1471-2156-9-84

Hoogerbrugge, N., van Domburg, R., van der Zwet, E., van Kemenade, M., Bootsma, A., \& Simoons, M. L. (2001). High fat intake in hyperlipidaemic patients is related to male gender, smoking, alcohol intake and obesity. Neth J Med, 59(1), 16-22. http://dx.doi.org/10.1016/S0300-2977(01)00119-X

James, N. A., \& Berry, B. W. (1997). Use of chevon in the development of low-fat meat products. J Anim Sci, 75(2), 571-577.

Knopp, R. H., Paramsothy, P., Retzlaff, B. M., Fish, B., Walden, C., Dowdy, A., ... Cheung, M. C. (2005). Gender differences in lipoprotein metabolism and dietary response: basis in hormonal differences and implications for cardiovascular disease. Curr Atheroscler Rep, 7(6), 472-479. http://dx.doi.org/10.1007/s11883-005-0065-6

Liméa, L., Alexandre, G., \& Berthelot, V. (2012). Fatty acid composition of muscle and adipose tissues of indigenous Caribbean goats under varying nutritional densities. $J$ Anim Sci, 90(2), 605-615. http://dx.doi.org/10.2527/jas.2010-3624

Lohner, S., Fekete, K., Marosvölgyi, T., \& Decsi, T. (2013). Gender differences in the long-chain polyunsaturated fatty acid status: systematic review of 51 publications. Ann Nutr Metab, 62(2), 98-112. http://dx.doi.org/10.1159/000345599

Maharani, D., Jung, Y., Jung, W. Y., Jo, C., Ryoo, S. H., Lee, S. H., ... Lee, J. H. (2012). Association of five candidate genes with fatty acid composition in Korean cattle. Mol Biol Rep, 39(5), 6113-6121. http://dx.doi.org/10.1007/s11033-011-1426-6

Mateo-Gallego, R., Perez-Calahorra, S., Cenarro, A., Bea, A. M., Andres, E., Horno, J., ... Civeira, F. (2011). Effect of lean red meat from lamb v. lean white meat from chicken on the serum lipid profile: a randomised, cross-over study in women. Br J Nutr, 1-5.

Mensink, R. P. (1993). Effects of the individual saturated fatty acids on serum lipids and lipoprotein concentrations. Am J Clin Nutr, 57(5 Suppl), 711S-714S.

Mensink, R. P., Temme, E. H., \& Hornstra, G. (1994). Dietary saturated and trans fatty acids and lipoprotein metabolism. Ann Med, 26(6), 461-464. http://dx.doi.org/10.3109/07853899409148369

Minihane, A. M., Khan, S., Leigh-Firbank, E. C., Talmud, P., Wright, J. W., Murphy, M. C., ... Williams, C. M. (2000). ApoE polymorphism and fish oil supplementation in subjects with an atherogenic lipoprotein phenotype. Arterioscler Thromb Vasc Biol, 20(8), 1990-1997. http://dx.doi.org/10.1161/01.ATV.20.8.1990

Peña, F., Bonvillani, A., Freire, B., Juárez, M., Perea, J., \& Gómez, G. (2009). Effects of genotype and slaughter weight on the meat quality of Criollo Cordobes and Anglonubian kids produced under extensive feeding conditions. Meat Sci.

Rhee, K.S., Cho, S. H., \& Pradahn, A. M. (1999). Composition, storage stability and sensory properties of expanded extrudates from blends of corn starch and goat meat, lamb, mutton, spent fowl meat, or beef. Meat Sci, 52(2), 135-141. http://dx.doi.org/10.1016/S0309-1740(98)00157-0

Rhee, K.S., Waldron, D. F., Ziprin, Y. A., \& Rhee, K. C. (2000). Fatty acid composition of goat diets vs intramuscular fat. Meat Sci, 54(4), 313-318. http://dx.doi.org/10.1016/S0309-1740(99)00094-7

Salazar,L. A., Hirata, M. H., Quintão, E. C., \& Hirata, R. D. (2000). Lipid-lowering response of the HMG-CoA reductase inhibitor fluvastatin is influenced by polymorphisms in the low-density lipoprotein receptor gene in Brazilian patients with primary hypercholesterolemia. $J$ Clin Lab Anal, 14(3), 125-131. http://dx.doi.org/10.1002/(SICI)1098-2825(2000)14:3\%3C125::AID-JCLA7\%3E3.0.CO;2-S

Sanchez-Muniz, F. J., Bastida, S., Viejo, J. M., \& Terpstra, A. H. (1999). Small supplements of N-3 fatty acids change serum low density lipoprotein composition by decreasing phospholid and apolipoprotein B concentrations in young adult women. Eur J Nutr, 38(1), 20-27. http://dx.doi.org/10.1007/s003940050042 
Solaiman, S., Min, B. R., Gurung, N., Behrends, J., \& McElhenney, W. (2012). Effects of breed and harvest age on feed intake, growth, carcass traits, blood metabolites, and lipogenic gene expression in Boer and Kiko goats. J Anim Sci. http://dx.doi.org/10.2527/jas.2011-3945

Tan, C. Y., Zhong, R. Z., Tan, Z. L., Han, X. F., Tang, S. X., Xiao, W. J., ... Wang, M. (2011). Dietary inclusion of tea catechins changes fatty acid composition of muscle in goats. Lipids, 46(3), 239-247. http://dx.doi.org/10.1007/s11745-010-3477-1

Vincent, S., Planells, R., Defoort, C., Bernard, M. C., Gerber, M., Prudhomme, J., ... Lairon, D. (2002). Genetic polymorphisms and lipoprotein responses to diets. Proc Nutr Soc, 61(4), 427-434. http://dx.doi.org/10.1079/PNS2002177

Viturro, E., Koenning, M., Kroemer, A., Schlamberger, G., Wiedemann, S., Kaske, M., \& Meyer, H. H. (2009). Cholesterol synthesis in the lactating cow: Induced expression of candidate genes. $J$ Steroid Biochem Mol Biol, 115(1-2), 62-67. http://dx.doi.org/10.1016/j.jsbmb.2009.02.011

Wheeler, T. L., Davis, G. W., Stoecker, B. J., \& Harmon, C. J. (1987). Cholesterol concentration of longissimus muscle, subcutaneous fat and serum of two beef cattle breed types. J Anim Sci, 65(6), 1531-1537.

Zhang, S.,Knight, T. J., Reecy, J. M., Wheeler, T. L., Shackelford, S. D., Cundiff, L. V., \& Beitz, D. C. (2010). Associations of polymorphisms in the promoter I of bovine acetyl-CoA carboxylase-alpha gene with beef fatty acid composition. Anim Genet, 41(4), 417-420.

Zulet, M. A., \& Martinez, J. A. (1995). Corrective role of chickpea intake on a dietary-induced model of hypercholesterolemia. Plant Foods Hum Nutr, 48(3), 269-277. http://dx.doi.org/10.1007/BF01088448

\section{Copyrights}

Copyright for this article is retained by the author(s), with first publication rights granted to the journal.

This is an open-access article distributed under the terms and conditions of the Creative Commons Attribution license (http://creativecommons.org/licenses/by/3.0/). 